\title{
PENGARUH PENAMBAHAN SERAT PELEPAH PISANG PADA PEMBUATAN PAVING BLOCK K-175
}

\author{
Abdus Salam', Sugeng Dwi Hartantyo ${ }^{2}$ \\ 'Program Studi Teknik Sipil Fakultas Teknik Sipil Universitas Islam Lamongan, \\ 2 Fakultas Teknik Universitas Islam Lamongan, \\ email : salam.id09@gmail.com,sugeng.dwih@gmail.com
}

\begin{abstract}
Pavingblock is one of the building material is used asthe top layer of the road structure other than asphalt or concrete. Today, many consumer preferring paving blocks compared to other pavement such as concrete or asphalt. That effort to improve the properties of the less good than paving blocks (eg, less tensile strength and brittle nature) can be done by adding fiber to mixing. One of the natural fiber used are banana midrib fiber, the use of banana midrib fiber as composite materialis a good step to reduce the pile of banana skins were strewn in the garden and also to raise the economic value of banana. The test object to be created is a test object with a mixture of 1: 3 with FAS 0.30 by compaction use manual / conventional, manufacture of each test specimens 3 pieces of normal test specimen without additives followed by paving block with material added together banana midrib fiber from 1\% - 5\% of the weight of cement used. Results of each - each of specimens have been tested for compressive strength of the test specimen normal to the specimen with additional fiber material as much as 5\%. Averages compressive strength calculation results in a sequence of test specimens $N$, $1 \%, 2 \%, 3 \%, 4 \%$ and $5 \%$, ie $224.20 \mathrm{~kg} / \mathrm{cm} 2,192.73 \mathrm{~kg} / \mathrm{cm} 2,119.97 \mathrm{~kg} / \mathrm{cm} 2,98.33$ $\mathrm{kg} / \mathrm{cm} 2,78.67 \mathrm{~kg} / \mathrm{cm} 2$, and $72.77 \mathrm{~kg} / \mathrm{cm} 2$.
\end{abstract}

Keywords: Paving Block, Banana Midrib Fiber, Compressive Strength.

\section{PENDAHULUAN}

Paving block merupakan salah satu bahan bangunan yang digunakan sebagailapisan atas struktur jalan selain aspal atau beton. Paving block adalah komposisi bahan bangunan yang terbuat dari campuransemen portland atau bahan perekat sejenis, air dan agregat halus dengan atautanpa bahan tambahan lainnya yang tidak mengurangi mutu dari pada betontersebut (SNI 03-0691-1996,Paving Block). Sekarang ini, banyak konsumenlebih memilih paving block dibandingkan perkerasan lain seperti beton maupun aspal.

Keberadaan paving dapat dijumpai ditrotoar, area bermain / taman, jalan lingkungan perumahan, hal itu terbukti, hampir diberbagai tempat seperti daerah parkiran, trotoar. Akan tetapi, tingginya permintaan konsumen terhadap paving tidak diimbangidengan ketersediaan kualitas yang memadai baik dari segi kekuatan, umur pakai. Banyak paving yang dijumpai pada permukaan jalanmengalami retak-retak, mudah patah, banyak ditumbuhi oleh lumut, karenapaving bersifat getas.. Hal ini disebabkan oleh mutu bahan yang tidak sesuai,gerusan air hujan, dan mungkin beban yang lewat diatasnya.

Bahwa upaya untuk memperbaiki sifatsifat yang kurang baik dari paving block (misalnya kuat tariknya kurang dan sifatnya yang getas) dapat dilakukan dengan cara menambah serat pada adukannya. Pemikiran dasarnya adalah menulangi beton dengan serat secara merata, dan orientasi penyebarannya secara acak, sehingga dapat mencegah 
terjadinya retakan-retakan dini, baik akibat panas hidrasi maupun akibat pembebanan.

Komposit serat alam merupakan salah satu material alternatif yang telah dikembangkan saat ini untuk pengganti bahan logam dan komposit sintetis. Serat alam mempresentasikan manfaat penting seperti densitas rendah, kekakuan dan sifat mekanik yang baik. Salah satu serat alam yang banyak digunakan adalah serat pelepah pisang, penggunaan serat pelepah pisang sebagai bahan komposit merupakan langkah yang baik guna mengurangi timbunan pelepah pisang yang berserakan dikebun dan juga untuk menaikkan nilai ekonimis dari pelepah pisang tersebut.

Pada kesempatan ini akan dilakukan suatu usaha untuk menghasilkan paving block dengan kuat tekan yang tinggi, penelitian ini mencoba mengaplikasikan penggunaan serat pelepah pisang sebagai bahan tambahan pada pembuatan paving block untuk memperbaiki kuat tekan pada paving block tersebut. Oleh karena itu penulis mengangkat judul "Pengaruh Penambahan Serat Pelepah Pada Pembuatan Paving Block K-175" pada laporan penelitian ini.

Adapun tujuan dari penelitian yaitu untuk mengetahui hasil kuat tekan dari penambahan serat pelepah pisang pada pembuatan paving block dan untuk mengetahui prosentase perbedaan antara paving block normal dengan paving block yang menggunakan bahan tambah serat pelepah pisang.

\section{METODE PENELITIAN}

Metode Penelitian ini dilakukan dengan cara metode eksperimen pengujian di laboratorium Teknik Sipil Universitas Islam Lamongan. Metode penelitian ini dilakukan dengan cara membandingkan kuat tekan paving block tanpa bahan tambahan serat pelepah pisang sebagai kontrol untuk mengetahui perbedaan yang terjadi pada paving block dengan dan tanpa bahan tambahan serat pelepah pisang tersebut.

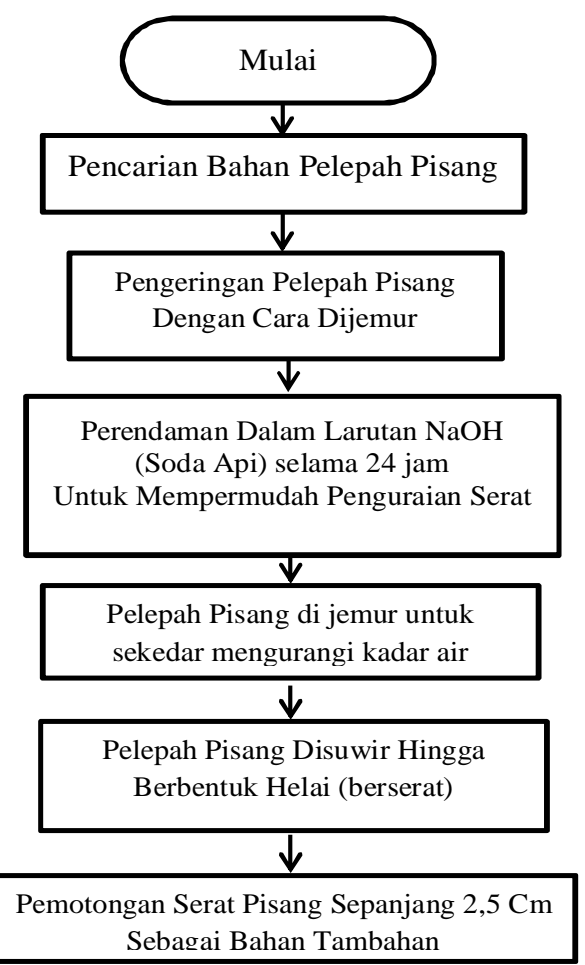

Gambar 1 Cara Pembuatan Serat Pelepah Pisang

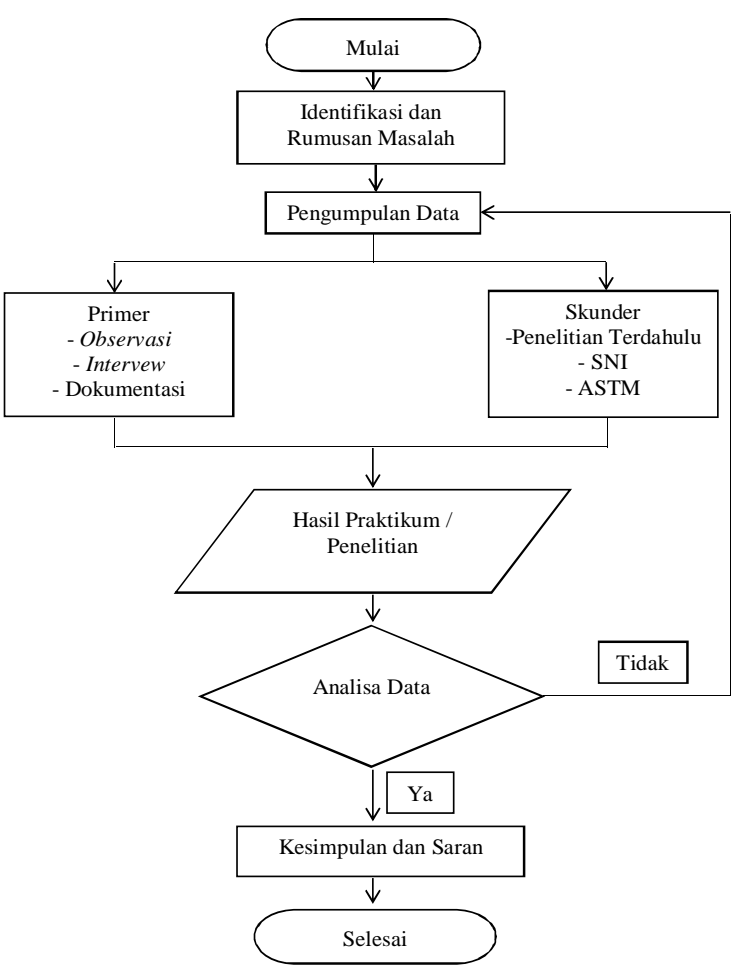

Gambar 2 Flow Chart

Pembuatan sampel sebagai benda uji untuk penelitian ini masing - masing benda uji sebanyak 3 benda uji. Untuk campuran produsen paving rata - rata menggunakan campuran $1: 2$ sampai dengan $1: 4$ dengan 
FAS yang rendah yaitu 0,30 mengingat semen akan berhidrasi dengan air minimum $25 \%$ dari berat semen tersebut. Melihat dari data diatas atas benda uji yang akan dibuat adalah benda uji dengan campuran $1: 3$ dengan FAS 0,30 dengan pemadatan menggunakan cara manual / konvensional.

Tabel 1Proporsi Pembuatan Benda Uji

\begin{tabular}{cccc}
\hline No & $\begin{array}{c}\text { Kode } \\
\text { Benda Uji }\end{array}$ & $\begin{array}{c}\% \\
\text { Serat }\end{array}$ & $\begin{array}{c}\text { Jumlah } \\
\text { Benda Uji }\end{array}$ \\
\hline 1 & $\mathrm{~N}$ & $0 \%$ & 3 buah \\
2 & $1 \%$ & $1 \%$ & 3 buah \\
3 & $2 \%$ & $2 \%$ & 3 buah \\
4 & $3 \%$ & $3 \%$ & 3 buah \\
5 & $4 \%$ & $4 \%$ & 3 buah \\
6 & $5 \%$ & $5 \%$ & 3 buah \\
\hline
\end{tabular}

Keterangan :

Penambahan serat pelepah pisang berdasarkan prosentase berat semen yang digunakan dalam campuran.

Proses Pembuatan Paving Block Normal (Kontrol) pertama buat adukan sebagai bahan baku paving block terlebih dahulu. Caranya dengan mencampurkan semen dan pasir memakai perbandingan 1:3 sesuai dengan landasan teori yang telah kita buat sealanjutnya tambahkan air dengan FAS 0,30 ke dalam adukan beton tadi pastikan hasil adukannya tidak terlalu basah kemudian jangan lupa atur terlebih dahulu posisi bagianbagian cetakan dan pastikan semuanya bagus setelah itu masukkan adukan ke dalam cetakan dengan volume menyesuaikan cetakan gunakan tongkat untuk memadatkan adukan paving block di dalam cetakan dengan memukulnya berkali-kali sampai diperoleh tingkat kepadatan yang diinginkan proses selanjutnya adalah mengeluarkan hasil cetakan yang telah jadi, lalu menempatkannya di tempat penyimpanan. Sebaiknya paving block mentah ini diletakkan di bidang yang mempunyai permukaan rata.

Sedangkan untuk pembuatan Paving Blockdengan bahan tambahan pertama buat adukan sebagai bahan baku paving block terlebih dahulu. Caranya dengan mencampurkan semen dan pasir memakai perbandingan 1 : 3 disertai dengan penambahan serat pelepah pisang dengan banyak sesuai dengan ketentuan benda uji yang telah dibuat untuk proses selanjutnya sama dengan proses pembuatan benda uji normal.

\section{HASIL DAN PEMBAHASAN}

Proses pengujian benda uji dilakukan di Laboratorium Teknik Sipil Universitas Islam Lamongan terhadap paving block yang telah berumur 7 hari sesuai dengan ketentuan dari pihak Universitas.

\section{Pengukuran dan Penimbangan Benda Uji}

Pada pengujian benda uji hal pertama yang dilakukan adalah pengukuran dan penimbangan semua benda uji. Data ukuran benda uji yang peneliti buat adalah sebagai berikut :

$\begin{array}{lllrl}\text { Panjang } & \text { ( p ) } & : & 20 & \mathrm{Cm} \\ \text { Lebar } & \text { ( 1 ) } & : & 10 & \mathrm{Cm} \\ \text { Tebal } & & : & 8 & \mathrm{Cm} \\ \text { Luas } & (\mathrm{L}) & : & 200 & \mathrm{Cm}^{2}\end{array}$

Semua benda uji berukuran sama karena menggunakan cetakan yang sama yaitu seperti data di atas.

Penimbangan benda uji dilakukan kepada semuan benda uji yang akan di uji, penimbangan ini dilakukan kepada semua benda uji untuk melihat bobot dari masing masing benda uji yang kemudain dicatat sebagai data.

Tabel 2 Hasil Penimbangan Benda Uji

\begin{tabular}{|c|c|c|c|c|}
\hline \multirow{2}{*}{$\begin{array}{c}\text { No } \\
1 \\
\end{array}$} & \multicolumn{2}{|c|}{$\begin{array}{c}\text { Kode } \\
\text { Benda Uji } \\
\end{array}$} & \multirow{2}{*}{$\begin{array}{c}\begin{array}{c}\text { Berat } \\
(\mathbf{k g})\end{array} \\
3,382\end{array}$} & \multirow[t]{2}{*}{$\begin{array}{c}\text { Rata - Rata } \\
(\mathrm{kg})\end{array}$} \\
\hline & $\mathrm{N}$ & 1 & & \\
\hline & & 2 & 3,33 & 3,36 \\
\hline & & 3 & 3,38 & \\
\hline \multirow[t]{3}{*}{2} & $1 \%$ & 1 & 3,345 & \\
\hline & & 2 & 3,425 & 3,37 \\
\hline & & 3 & 3,332 & \\
\hline \multirow[t]{3}{*}{3} & $2 \%$ & 1 & 3,425 & \\
\hline & & 2 & 3,263 & 3,34 \\
\hline & & 3 & 3,319 & \\
\hline \multirow[t]{3}{*}{4} & $3 \%$ & 1 & 3,28 & \\
\hline & & 2 & 3,265 & 3,24 \\
\hline & & 3 & 3,165 & \\
\hline \multirow[t]{3}{*}{5} & $4 \%$ & 1 & 3,1 & \\
\hline & & 2 & 3,128 & 3,15 \\
\hline & & 3 & 3,225 & \\
\hline \multirow[t]{3}{*}{6} & $5 \%$ & 1 & 3,21 & \\
\hline & & 2 & 3,223 & 3,20 \\
\hline & & 3 & 3,168 & \\
\hline
\end{tabular}




\section{Pengujian Kuat Tekan}

Proses pengujian kuat tekan dilakukan setelah semua benda uji telah selesai dilakukan pengukuran dan penimbangan. Proses pengujian dilakukan guna mendapatkan hasil apakah penelitian yang dilakukan dengan cara menambahkan serat pelepah pisang ini dapat memeperbaiki daya kuat tekan paving block atau sebaliknya.

Pelaksanaan pengujian kuat tekan beton harus diikuti beberapa tahapan sebagai berikut:

- Ambil benda uji yang akan diuji

- Hitung Luas Penampang benda uji sebelum diuji sebagai data untuk perhitungan kuat tekan paving block

- Letakkan benda uji pada mesinpenekan dengan posisi yang datar kemudian contoh benda uji yang siap, ditekan hingga hancur dengan mesin penekan.

Catat data atau beban yang terjadi sampai benda uji itu hancur ( ton ), untuk kemudian dihitung nilai kuat tekan yang terjadi sebagai hasil.

Rumus perhitungan kuat tekan

Kuat tekan $(\mathrm{Kg} / \mathrm{cm} 2)=\frac{P}{L} \times \mathrm{c}$

Ket : $\quad \mathrm{P}=$ tekanan hancur

$\mathrm{L}=$ luas penampang $(200 \mathrm{~cm} 2)$

$\mathrm{c}=$ factor chamfered $(1,18)$

Karena bentuk paving block yang dibuat mempunyai sisi chamfered maka perhitungan mengikuti tata cara perhitungan berdasarkan faktor chamfered yaitu 1,18 untuk paving dengan tebal $8 \mathrm{~cm}$ (Spec Precast Concrete Paving Blocks, Cemen and Concrete Association County Surveyors Society Interpave 1980)

Tabel 3 Nilai Faktor Chamfered

\begin{tabular}{|c|c|c|}
\hline block thickness (mm) & plain block & chamfered block \\
\hline 60 or 65 & 1.00 & 1.06 \\
\hline 80 & 1.12 & 1.18 \\
\hline 100 & 1.18 & 1.24 \\
\hline
\end{tabular}

Sumber : Spec Precast Concrete Paving Blocks, Cemen and Concrete Association County Surveyors Society Interpave 1980

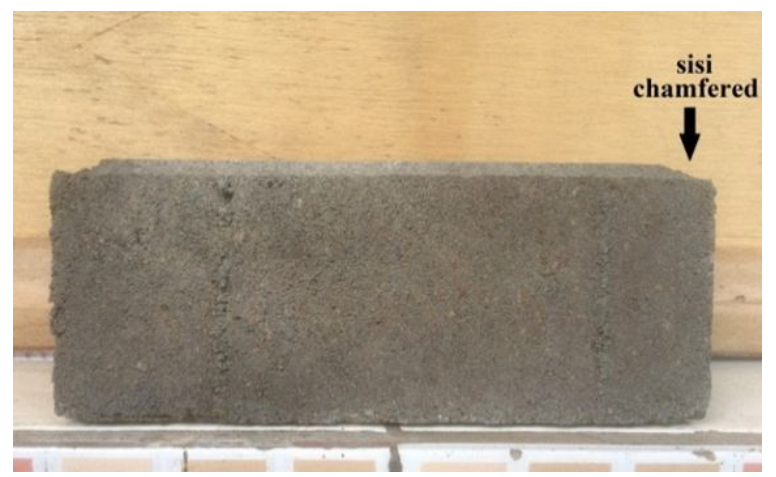

Gambar 3 Sisi Chamfered Benda Uji

Setelah semua benda uji telah kita tes data sudah kita dapatkan kita dapat menuysun data selanjutnya yaitu kuat tekan rata - rata .Kuat tekan rata - rata dari benda uji dihitung dari jumlah kuat tekan dibagi jumlah benda uji.

Kuat Tekan Rata - Rata $=\frac{\text { Kuat Tekan } B U-\ldots(A+B+C)}{\text { Jumlah Benda } U j i}$

Tabel 4 Hasil Uji Kuat Tekan

\begin{tabular}{|c|c|c|c|c|c|c|}
\hline \multirow{2}{*}{ No } & \multirow{2}{*}{\multicolumn{2}{|c|}{$\begin{array}{c}\text { Kode } \\
\text { Benda } \\
\text { Uji }\end{array}$}} & Berat & $\begin{array}{l}\text { Tekanan } \\
\text { Hancur }\end{array}$ & $\begin{array}{c}\text { Kuat } \\
\text { Tekan }\end{array}$ & $\begin{array}{c}\text { Rata - } \\
\text { Rata }\end{array}$ \\
\hline & & & $(\mathrm{kg})$ & $\begin{array}{c}\text { (ton) } \\
\mathbf{P}\end{array}$ & $\begin{array}{l}(\mathrm{kg} / \\
\mathrm{cm} 2)\end{array}$ & $\begin{array}{c}(\mathrm{kg} / \\
\mathrm{cm} 2)\end{array}$ \\
\hline \multirow[t]{3}{*}{1} & $\mathrm{~N}$ & 1 & 3,382 & 35 & 206,50 & \\
\hline & & 2 & 3,33 & 41 & 241,90 & 224,20 \\
\hline & & 3 & 3,38 & 38 & 224,20 & \\
\hline \multirow[t]{3}{*}{2} & $1 \%$ & 1 & 3,345 & 36 & 212,40 & \\
\hline & & 2 & 3,425 & 28 & 165,20 & 192,73 \\
\hline & & 3 & 3,332 & 34 & 200,60 & \\
\hline \multirow[t]{3}{*}{3} & $2 \%$ & 1 & 3,425 & 19 & 112,10 & \\
\hline & & 2 & 3,263 & 22 & 129,80 & 119,97 \\
\hline & & 3 & 3,319 & 20 & 118,00 & \\
\hline \multirow[t]{3}{*}{4} & $3 \%$ & 1 & 3,28 & 19 & 112,10 & \\
\hline & & 2 & 3,265 & 17 & 100,30 & 98,33 \\
\hline & & 3 & 3,165 & 14 & 82,60 & \\
\hline \multirow[t]{3}{*}{5} & $4 \%$ & 1 & 3,1 & 12 & 70,80 & \\
\hline & & 2 & 3,128 & 13 & 76,70 & 78,67 \\
\hline & & 3 & 3,225 & 15 & 88,50 & \\
\hline \multirow[t]{3}{*}{6} & $5 \%$ & 1 & 3,21 & 12 & 70,80 & \\
\hline & & 2 & 3,223 & 13 & 76,70 & 72,77 \\
\hline & & 3 & 3,168 & 12 & 70,80 & \\
\hline
\end{tabular}

Dapat dilihat pada tabel 4 semua data dari masing - masing benda uji dari benda uji 
normal sampai dengan benda uji dengan bahan tambahan serat sebanyak 5\%. Rata rata hasil perhitungan kuat tekan secara berurutan dari benda uji N, $1 \%, 2 \%, 3 \%, 4 \%$ dan $5 \%$ yaitu $224,20 \mathrm{~kg} / \mathrm{cm} 2,192,73 \mathrm{~kg} / \mathrm{cm} 2$, $119,97 \mathrm{~kg} / \mathrm{cm} 2, \quad 98,33 \quad \mathrm{~kg} / \mathrm{cm} 2, \quad 78,67$ $\mathrm{kg} / \mathrm{cm} 2$, dan $72,77 \mathrm{~kg} / \mathrm{cm} 2$.

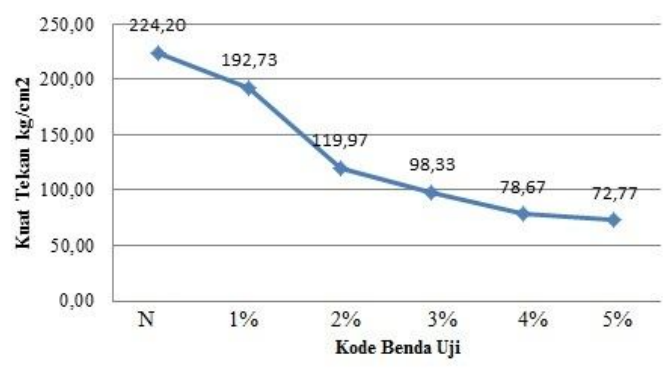

Gambar 4 Diagram hasil kuat tekan $\mathrm{kg} / \mathrm{cm} 2$

Kemudian dari hasil kuat tekan $\mathrm{kg} / \mathrm{cm} 2$ tersebut di konversi ke satuan Mpa dengan ketentuan sebagai berikut :

Tabel 5 Perbandingan kuat tekan beton pada berbagai benda uji

\begin{tabular}{|l|c|}
\hline \multicolumn{1}{|c|}{ benda uji } & perbandingan kuat tekan \\
\hline kubus $15 \mathrm{~cm} \times 15 \mathrm{~cm} \times 15 \mathrm{~cm}$ & 1.00 \\
\hline kubus $20 \mathrm{~cm} \times 20 \mathrm{~cm} \times 20 \mathrm{~cm}$ & 0.95 \\
\hline silinder dia. $15 \mathrm{~cm}$, tinggi $30 \mathrm{~cm}$ & 0.83 \\
\hline
\end{tabular}

Sumber : Peraturan Beton Bertulang Indonesia (PBI) 1971 N.I. -2

Contoh perhitungan benda uji Normal $\mathrm{K}-224,2$ setara dengan $\mathrm{fc}^{\prime}=20,89 \mathrm{Mpa}$

Konversi ke kubus

$20 \mathrm{~cm} \times 20 \mathrm{~cm} \times 20 \mathrm{~cm}=224,2 \times 0,95$

Konversi satuan ke Mpa

$$
=212,99 \mathrm{~kg} / \mathrm{cm} 2
$$

$212,99 \times 9,81 / 100=20,89 \mathrm{Mpa}$

Tabel 6 Konversi Satuan Kuat Tekan Kg/cm2 ke Mpa

\begin{tabular}{cccc}
\hline \multirow{2}{*}{ No } & $\begin{array}{c}\text { Kode } \\
\text { Benda }\end{array}$ & \multicolumn{2}{c}{ Kuat Tekan } \\
\cline { 3 - 4 } & Uji & (kg/cm2) & Mpa \\
\hline 1 & $\mathrm{~N}$ & 224,20 & 20,89 \\
2 & $1 \%$ & 192,73 & 17,96 \\
3 & $2 \%$ & 119,97 & 11,18 \\
4 & $3 \%$ & 98,33 & 9,16 \\
5 & $4 \%$ & 78,67 & 7,33 \\
6 & $5 \%$ & 72,77 & 6,78 \\
\hline
\end{tabular}

Dari tabel 5 dapat kita lihat hasil dari konversi kuat tekan $\mathrm{kg} / \mathrm{cm} 2 \mathrm{ke}$ Mpa dengan nilai berurutan dari benda uji $\mathrm{N}, 1 \%, 2 \%, 3 \%$,
4\% dan 5\% adalah 20,89 Mpa, 17,96 Mpa, 11,18 Mpa, 9,16 Mpa, 7,3 Mpa, dan 6,78 Mpa.

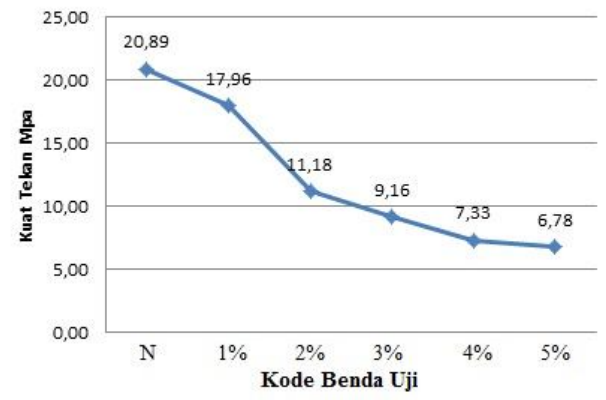

Gambar 5 Diagram hasil kuat tekan Mpa

Tabel 7 Prosentase Peningkatan / Penurunan Kuat Tekan

\begin{tabular}{ccccc}
\hline & $\begin{array}{c}\text { Kode } \\
\text { Benda } \\
\text { Uji }\end{array}$ & $\begin{array}{c}\text { Tegangan } \\
\text { Hancur }\end{array}$ & $\begin{array}{c}\text { Perbandingan } \\
\text { Prosentase }\end{array}$ & $\begin{array}{c}\text { Prosentase } \\
\text { Penurunan }\end{array}$ \\
\cline { 3 - 5 } & & Mpa & & \% \\
\hline 1 & $\mathrm{~N}$ & 20,89 & 100,00 & - \\
2 & $1 \%$ & 17,96 & 85,96 & -14 \\
3 & $2 \%$ & 11,18 & 53,51 & -46 \\
4 & $3 \%$ & 9,16 & 43,86 & -56 \\
5 & $4 \%$ & 7,33 & 35,09 & -65 \\
6 & $5 \%$ & 6,78 & 32,46 & -68 \\
\hline
\end{tabular}

Dapat dilihat dari tabel 6 bahwa hasil dari daya kuat berurutan dari benda uji $\mathrm{N}$, $1 \%, 2 \%, 3 \%, 4 \%$ dan $5 \%$ adalah $0 \%,-14 \%$, $46 \%,-56 \%,-65 \%,-68 \%$. Dari hasil diatas kuat tekan dari benda uji mengalami penurunan seiring bertambahnya serat yang ditambahkan pada campuran.

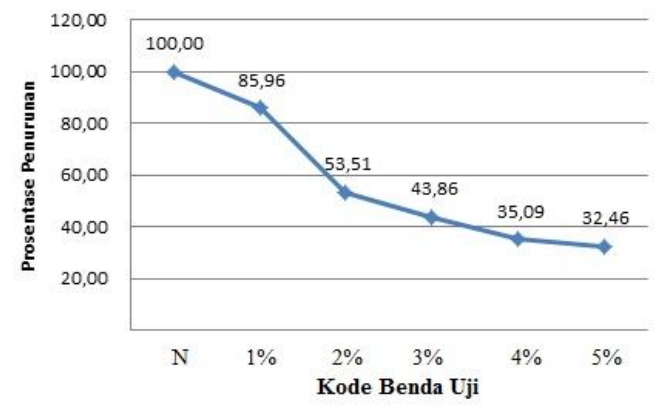

Gambar 6 Diagram prosentase hasil kuat tekan.

\section{Pembahasan}

Adapun beberapa hal yang mungkin berhubungan dengan penurunan kuat tekan 
dari paving blok ini mungkin disebabkan dari berat dari benda uji yang mengalami perbedaan, karena nilai berat paving block menunjukkan kepadatan dari paving block tersebut. Kepadatan yang kecil, berarti mengurangi kuat tekan. Karena saat paving block ditekan akan memampat dan material didalam paving block akan mendesak mengisi rongga-rongga yang ada sehingga menyebabkan kerusakan atau patah.

Serta dari bahan serat pelepah pisang yang digunakan, secara mekanis serat pelepah pisang memiliki daya serap (hidrolisis) terhadap air yang tinggi. Sifat hidrolisis yang dimiliki serat pelepah pisang tersebut dimungkinkan mengganggu reaksi pengikatan agregat oleh semen. Ini disebabkan karena untuk mengikat agregat, semen membutuhkan air yang cukup. Disamping itu air banyak diserap oleh serat pelepah pisang yang ada dalam campuran. Sehingga kuat tekan yang dihasilkan menurun.

Selain berat dan sifat serat pelepah pisang, besarnya kekuatan pemadatan pada pemadatan manual juga berpengaruh terhadap kuat tekan paving. Semakin rendah kuat pemadatannya maka kuat tekan paving block semakin menurun, hal ini disebabkan karena rongga dalam paving block yang kosong. Dengan pemadatan yang besar maka kuat tekan paving block akan bertambah, karena rongga-rongga akan terisi.

\section{KESIMPULAN}

1. Kuat tekan paving block yang dihasilkan dari penambahan serat pelepah pisang rata - rata secara berurutan dari benda uji $\mathrm{N}, 1 \%, 2 \%, 3 \%, 4 \%$ dan $5 \%$ adalah 20,89 Мрa, 17,96 Мpa, 11,18 Мpa, 9,16 Mpa, 7,3 Mpa, dan 6,78 Mpa. Kuat tekan dari dari paving block yang di buat mengalami penurunan seiring bertambahnya prosentase penambahan serat pelepah pisang. Rata - rata kuat tekan normal adalah 20,89 Mpa dan rata - rata kuat tekan terendah terdapat pada campuran 5\% yaitu 6,78 Mpa.

2. Prosentase kuat tekan berurutan dari benda uji N , 1\%, 2\%, 3\%, 4\% dan $5 \%$ adalah $0 \%,-14 \%,-46 \%,-56 \%,-65 \%$, $68 \%$. Berdasarkan hasil peneitian ini maka serat pelepah pisang tidak dapat digunakan sebagai bahan tambahan pada penelitian ini untuk memperbaiki daya kuat tekan dari paving block

\section{Saran}

Perlu adanya penelitian lebih lanjut mengenai penggunaan serat pelepah pisang sebagai bahan tambahan pembuatan paving block. Adanya penelitian lanjutan tersebut adalah penggunaan mesin cetakan hidrolis yang telah terukur bebannya pada saat pencetakan, penggunaan variasi nilai FAS, serta variasi perbandingan jumlah semen dengan agregat agar diperoleh kuat tekan yang lebih baik.

\section{DAFTAR PUSTAKA}

Ananda. F, Musayafa, Zarina, Suhairi. 2016. Pengaruh Penambahan Serat Ijuk dan Kawat Bendrat Pada Paving Block. Inovtek, Volume 6, Nomor 2, Oktober 2016, hlm. 68 - 72

ASTM C.125-1995:61,"Standard Definition of Terminology Relating to Concrete and Concrete Agregates" dan dalam ACI SP19, "Cement and Concrete Terminology",

Buku Pedoman Praktikum Bahan Beton. 2014. Fakultas Teknik Universitas Islam Lamongan.

Eratodi. Ariawan, P . 2016. Rekayasa Semen Komposit Limbah Serutan Bambu Sebagai Bahan Alternatif Perkerasan Jalan (Paving Block). Jurnal Teknik Sipil Volume 14, No. 1, Oktober 2016, 20-28.

Firmanyah, D. 2012. Pemanfaatan Sisa Pembakaran Ampas Tebu Sebagai Bahan Pengisi Dalam Proses Pembuatan Paving Dengan Semen Jenis PCC. Scaffolding 1 (2) Jurnal Teknik Sipil, Fakultas Teknik, Universitas Negeri Semarang

Kartini. W . 2007 . Penggunaan Serat Polypropylene Untuk Meningkatkan Kuat Tarik Belah Beton. Jurusan Teknik Sipil - UPN"Veteran" Jatim.

Lokantara, P. 2012. Analisis Kekuatan Impact Komposit Polyester-Serat Tapis Kelapa Dengan Variasi Panjang Dan Fraksi Volume Serat Yang Diberi Perlakuan $\mathrm{NaOH}$, Fakultas Teknik, Universitas Udayana, Kampus Bukit Jimbaran, Bali, Indonesia. 
Nopriantina. N, Astuti. 2013 . Pengaruh Ketebalan Serat Pelepah Pisang Kepo (Musa Paradisiaca) Terhadap Sifat Mekanik Material Komposit PoliesterSerat Alam. Jurusan Fisika FMIPA Universitas Andalas Kampus Unand, Limau Manis, Padang, 25163

Sarjono, W. Wajono, A. P. 2008. Jurnal Pengaruh Penambahan Serat Ijuk Pada Kuat Tarik Campuran Semen-Pasir Dan Kemungkinan Aplikasinya. Jurnal Teknik Sipil Volume 8 No. 2, Pebruari 2008 : 159 - 169. Universitas Atma Jaya. Yogyakarta

SNI 03-0691-1996 Tentang Bata Beton (Paving Block)

SNI 03-2834-2000 Tata Cara Pembuatan Rencana Campuran Beton Normal

Soroushian . Bayasi, Z., 1987, Concept of Fiber Reinforced Concrete, Proceding of The International Seminar on Fiber Reinforced Concrete, Michigan State University, Michigan.

Spec Precast Concrete Paving Blocks, Cemen and Concrete Association County Surveyors Society Interpave 1980.

Surrani, L., 2010, Pemanfaatan Batang Pisang (musa sp.) sebagai Bahan Baku Papan Serat dengan Perlakuan TermoMekanis, Balai Penelitian Kehutanan, Manado.

Tjokrodimuljo, K., 1996. Teknologi Beton, Nafiri. Yogyakarta

Peraturan Beton Bertulang Indonesia (PBI) 1971 N.I. -2

Wianto. T, Abdurrahman. M, Fajar F A. 2014. Pemanfaatan Serat Pelepah Pisang Sebagai Material Komposit Poliester Dalam Pembuatan Tempurung Helm Yang Ekonomis Dan Ramah Lingkungan. Innovative Materials Engineering Competition (IMEC) 2014. Institut Teknologi dan Sains Bandung Kota Deltamas - Kab. Bekasi.

http://tukangpaving.blogspot.co.id/2015/06/pe ngertian-paving-block.html diakses tanggal 09 Nopember 2016 pukul 20:06 WIB

http://www.badatanci.com/2014/03/komposisi -semen-portland-danfungsinya.html di akses tanggal 17 Januari 2017 pukul 21:15 WIB http://lauwtjunnji.weebly.com/pbi-sni-satuan-dan-benda-uji.html di akses tanggal 16 Maret 2017 pukul 20:05 WIB 
Halaman ini sengaja dikosongkan 